\title{
LÍRICA Y SOCIEDAD EN GRECIA ARCAICA: UNA CONTRIBUCIÓN
}

J. A. López Ferez

UNED

\section{LÍRICA Y ESCRITURA}

La escritura alfabética se introdujo en Grecia a mediados del siglo viII a. C., siendo un dato bien señalado por los estudiosos el que en Homero sólo se la menciona una vez (Il. VI 168-170). A fines del siglo viI, según criterio casi unánime, se fijan por escrito los poemas homéricos y las obras de Hesíodo. Como es sabido, Homero está al final de una larga etapa en que la épica había sido transmitida oralmente.

Con respecto a la Lírica, en cuyos origenes hay que ver una estrecha relación con la fiesta, estamos mal informados acerca de sus manifestaciones preliterarias, pero lo cierto es que cobró notable impulso en el siglo VIII a. C. La creación de las grandes festividades griegas a lo largo del siglo vIII (los Juegos Olimpicos fueron celebrados por vez primera en el 776 a. C.), $\mathrm{y}$, especialmente, durante el vII, contribuyó notablemente al desarrollo de la lírica en sus diversas manifestaciones. Aun así, la lírica del siglo viII no se fijó por escrito, es preliteraria. No obstante, encontramos reflejos de la misma en Homero. Así, Il. XVIII 567 ss. nos informa de coros de vírgenes y jóvenes que acompañan a un citaredo que canta el lino, canción de duelo y de cosecha; XVIII 490 ss. nos presenta escenas de boda con coros y cantos de himeneo; I 473 ss. alude a los aqueos que cantan el peán; XXIV 723 ss. se refiere a los aedos solistas que están presentes en los funerales de Héctor. Igualmente, en los proemios de Hesíodo nos informamos acerca de los himnos cantados por las propias musas. Pues bien, peán, himeneo, himno serán composiciones importantes dentro de la lírica literaria posterior.

Desde mediados del siglo vir a. C. contamos con las poesías de Arquí- 
loco, en las que la presencia de fórmulas homéricas es un dato relevante. Por lo demás, ciertos rasgos típicos de la poesía oral son patentes en $\mathrm{Ar}$ quíloco y otros yambógrafos y elegíacos arcaicos.

\section{Precisiones SOBRE EL TÉRMINO «LíriCA»}

El vocablo «lírica» es confuso, al menos en un primer acercamiento. En Literatura griega hay que entender «lírica» como la poesía apropiada para el canto, vaya o no acompañada de lira. Por oposición a la épica cantada (aeidein) por el aedo con acompañamiento de fórminge, instrumento de cuerda, la lírica, desde el siglo VII, es cantada a los sones de la doble flauta (aulós): tanto la elegiaca (constituida de dísticos elegiacos), como la yámbica. La flauta viene asociada a la música asiática desde Homero (Il. X 13), $\mathrm{y}$, como es bien sabido, la lírica literaria griega comienza con brío en tierras cercanas a Asia (las islas), o en la propia Asia (Jonia).

La lira, instrumento griego, desarrollado quizá a partir de la fórminge homérica (Terpandro inventa la lira de siete cuerdas en el siglo VII a. C.), tiene gran importancia en la lírica monódica y coral a partir del VII a. C.

\section{Elegía Y YAMBo}

La elegía, heredera directa de la poesía homérica, hexamétrica, es más bien un producto artificial: un hexámetro dactílico seguido de un pentámetro. Puede admitirse que fue inventada en Asia. En todo caso, tuvo rápido desarrollo literario y sustituyó a varios metros tradicionales: hexámetros (himnos), anapestos (en la parénesis de un Tirteo), yambos (en las elegías de escarnio y burla). La elegía es literatura desde sus comienzos, ha nacido con fines exclusivamente literarios. Es una cuestión polémica el origen trenético (canto fúnebre) de la elegía', pero, en todo caso, hay un uso literario tal desde Arquíloco. Recordemos dos datos interesantes: la elegía trenética no es usada más que una vez en la tragedia (Eurípides, Andr. 103116); y los epigramas sepulcrales en dísticos elegiacos aparecen a partir del

B. GeNTILI, «Epigramma ed elegia», en L'epigramme grecque, Ginebra-Vandoeuvres 1969, pp. 39 ss. 
siglo vi a. C. Hasta tal momento esos epigramas eran escritos en hexámetros.

Por su lado, el yambo deriva directamente de rituales populares asociados a diversas divinidades relacionadas con el ciclo de las cosechas y con la fertilidad (Deméter, Dioniso). El yambo, de uso normal en las fiestas dionisiacas, respondía más bien a la manifestación de un sentimiento popular que a la expresión de un ataque o rencor personal. Tal carácter tuvo también en la Comedia ática. El llamado género yámbico comprende tres esquemas métricos: trímetros yámbicos, tetrámetros trocaicos y epodos. Las dos primeras estructuras métricas eran usadas en la poesía griega popular en toda Grecia en fechas anteriores a la lírica literaria. Del género yámbico están excluidos el himno y el treno.

\section{LA SOCIEDAD GRIEGA DESDE COMIENZOS DEL SIGLO VII A. C.}

En primer lugar, la colonización griega, impulsada de forma decisiva desde mediados del siglo vilI a. C., fue generando nuevas colonias y establecimientos en el Mediterráneo oriental. Algunos de esos nuevos asentamientos se destacaron rápidamente por su riqueza y su cultura. A partir del siglo VII a. C. sabemos de una serie de poetas locales que nos ofrecen datos, en extremo interesantes, para saber del nacimiento, desarrollo y circunstancias económicas y sociales de algunas de esas colonias griegas: Arquiloco en Paros, Alceo y Safo en Lesbos, Calino e Hiponacte en Éfeso, Semónides en Amorgos, etc., son buena prueba de lo que decimos. Asimismo, como adelantamos, hubo concursos, que bien podemos llamar internacionales, de lírica literaria desde el siglo vil a. C.

De otra parte los poetas líricos tuvieron una gran importancia en la cultura propiciada por los gobernantes del momento, que procuraban atraerse a los mejores desde diversas partes del mundo griego. Así, la realeza espartana llamó, entre otros, a Alcmán, quizá de Sardes, y a Estesicoro de Hímera; los tiranos se disputaron, asimismo, a los líricos más descollantes del momento: Arión de Metimna trabajó en Corinto; Íbico de Regio, en Samos y Atenas; Anacreonte de Teos, en Samos, Atenas y Tesalia; Simónides de Ceos, Baquílides de Ceos y Píndaro de Tebas irán, de aquí para allá, requeridos por los más encumbrados próceres de su época.

\section{LIRICA Y CIUDAD}

Un elemento de extraordinaria importancia para la producción y desarrollo de la lírica literaria desde sus comienzos es el surgir de las ciudades 
griegas. Es muy probable que donde nacieron las primeras póleis fuera en el litoral egeo de Asia Menor. En ellas se dieron circunstancias diferentes a las propias de las metrópolis originarias. Efectivamente, junto al sentimiento particularista traído desde la Grecia peninsular, brotó el individualismo propio de quien ha abandonado su solar patrio y todo vínculo tradicional. A todo ello vino a sumarse la viva conciencia de ser griegos, y, por tanto, diferentes de las poblaciones indígenas. En tales ciudades los cultos familiares de los géné más destacados se convirtieron en el culto oficial.

De la vida en común propia del territorio peninsular griego basada en un sistema feudal, aristocrático, se pasó a un sentimiento político diverso establecido sobre la ley y el orden. No es, en absoluto, contradictorio que surjan al mismo tiempo la personalidad individual y el sentido de orden y justicia propio de la ciudad, pues ser ciudadano es algo muy diferente de pertenecer a una masa de sometidos a la voluntad despótica de un amo.

Tales realidades politicas y sociales debieron de contribuir en grado no pequeño al surgimiento de la lírica en las ciudades griegas de Asia Menor. Así, si la épica narra en tercera persona sucesos de un pasado mítico, pues el aedo se oculta en cierto modo tras las palabras de sus personajes, la lírica, desde sus primeras manifestaciones es dirigida por un "yo" (el poeta) a un «tú» (o «vosotros») sobre el que quiere causar influencia evidente, su contenido aparece referido a un "aquí» y un «ahora».

La ciudad está lejos de la atención de Hesíodo, por ejemplo, más preocupado por las repercusiones personales de la injusticia. En la lírica, en cambio, el tema de injusticia es enfocado, ante todo, en su reflejo sobre el equilibrio ciudadano, en las relaciones humanas dentro de la ciudad. Alceo, por poner un caso conspicuo, se interesa por el tema de la justicia, porque él, personalmente, está en contra de la ruptura del equilibrio hasta entonces existente entre los nobles de su ciudad, y, por tanto, rechaza la tiranía.

La ciudad, entre los líricos, es un tema de gran relevancia, desde Arquíloco hasta Píndaro. Por acudir a un recuento numérico digamos que en ellos aparece frecuentemente pólis (168 secuencias) y polítēs (14). Verdad es que Píndaro, por ejemplo, escribe por encargo, pero, aun así, se ajusta a las exigencias de una determinada ciudad (o individuo) y sus cantos son entonados en fiestas a que concurre normalmente toda una ciudad o un grupo selecto de ella. El propio poeta asiste a veces a tal acontecimiento.

Desde mediados del vir a. C. Arquíloco nos sorprende tomando parte activa en las campañas militares organizadas por su ciudad (Paros) para la conquista de Tasos: afirma que los dioses olimpicos intervienen en favor de su ciudad, saca a colación el tema de la nave del Estado, lo organiza todo, en suma, en torno a su ciudad.

El poeta lírico se dirige a una ciudad entera (Arquíloco, Tirteo, Calino Alcmán, Estesícoro, Solón, Píndaro), o a un grupo de ciudadanos (Alceo, Safo), o a una sola persona (Safo). Son, por lo común, poemas cantados 
ante un auditorio al que se trata de incitar a la acción. Los oyentes participan en una fiesta, en un banquete, en la guerra. Son actos organizados por la ciudad, casi siempre.

El poeta se nombra a sí mismo, tiene conciencia de su personalidad y valia, se considera un sabio. [En los líricos tenemos registrada con frecuencia la pareja sophós (58), sophia (38). Para Píndaro "sabio es el que tiene mucha ciencia por naturaleza» (I. I 45); «los hombres nacen distinguidos y hábiles por concesión divina» ( $O$. IX 28).]

\section{Delimitación de nuestro estudio}

Nos limitaremos al examen de los elegiacos y yambógrafos más relevantes, y, además, abordaremos parcialmente las poesías de Alcmán, por fijarnos en un autor destacado dentro de la lírica coral. Nos ceñiremos a la relación entre lírica y sociedad. Nos interesamos, de modo especial, por la sociedad para la que se escribieron los poemas, más que por la sociedad en sí misma, tal como queda reflejada en los líricos. Es decir, nuestro dificil objetivo es procurara deslindar para quiénes escribían los líricos, procurando dar las razones de ello.

\section{YAMBÓGRAFOS Y ELEGIACOS}

\section{a) Arquíloco}

Natural de Paros, su floruit puede establecerse en 665-664 a. C. Según un testimonio de Pausanias (X 28, 3) su abuelo, o bisabuelo, habia llevado el culto de Deméter a Tasos. El propio poeta, en varios fragmentos, muestra su especial relación con Dioniso. Por todo ello debemos colegir que gran parte de sus yambos estaban dedicados al culto y habían sido cantados delante de todo el pueblo en ocasión de fiestas especiales. Ante todo, y en relación con el aspecto que nos interesa, nos hallamos ante un problema literario. Pues como Dover demostró ${ }^{2}$, no hay argumentos suficientes, ni

${ }^{2}$ K. Dover, "The poetry of Archilochos", en Archiloque, Ginebra-Vandoeuvres 1963, pp. 183-212. 
lingüisticos ni de contenido, para separar las elegías de los yambos arquiloqueos. Así, tanto las elegías como los yambos pueden ser dirigidos a individuos concretos; el carácter gnómico, o sea, las máximas o sentencias de carácter general, se encuentran en ambas estructuras métricas; prácticamente todos los motivos literarios que hallamos en las elegías los tenemos también en los yambos, pero no al revés. La obscenidad más descarada no se da en las elegías, y los elementos luctuosos no aparecen en los yambos. Aun así, hemos de tener en cuenta que las elegias suponen unos 50 versos, es decir, mucho menos que lo conservado del género yámbico, por lo que es al menos arriesgado dar cortes tajantes entre una y otra estructura métrica en atención al contenido.

Otro escollo que encontramos es que "yo" no siempre significa la persona del poeta, como bien reconoció Aristóteles ( $R h .1418$ b 23 ss.). Pero no conviene exagerar, ni pretender que todo es ficción poética. Se ha dicho que Licambes y sus hijas podrian ser meros temas literarios, pues no eran contemporáneos del poeta. Pero, con todo, nadie pone en duda que Glauco y Pericles, citados por Arquíloco, son personajes reales e históricos.

Pues bien, en los trímetros yámbicos leemos descripciones de la isla de Tasos $(106,107)$, elementos eróticos $(104,130)$, o claramente obscenos $(116$, $125)$, o poemas de ataque como los dirigidos contra Licambes $(122,132$, 142). Buena parte de estas composiciones yámbicas debieron de haber sido cantadas en fiestas populares en que tales libertades (ataque, obscenidad, alusiones sexuales) eran normales. $Y$ no olvidemos que con frecuencia la libertad de palabra tenía un claro fin político, social: sacar a la luz las verdades ocultas, denunciar la corrupción. De ahí, la continua apelación a los ciudadanos.

Quizás tienen mayor libertad de lenguaje los epodos, elevados por Arquíloco a categoría literaria. Están ligados al culto demetriaco o dionisiaco, y en ellos suele haber un mito o fábula, aparte del tema amoroso o de ataque. Ya desde Hesíodo, la fábula es elemento de gran importancia en la tradición didáctica popular. En la misma línea está el último epodo de Arquíloco publicado en 1973, donde el poeta, o "yo» poético, acaricia y ama en un prado a la hermana menor de Neobula sin llegar a la culminación del acto sexual.

Por su parte, los tetrámetros trocaicos más destacados abordan temas gnómicos y están dedicados al banquete: las alternativas del hombre (211), la conveniencia de confiar en los dioses (207), Pericles el gorrón (216), etc., son motivos sobresalientes.

De carácter bien distinto son las elegias. Cantadas en el banquete no suelen abordar temas obscenos, y, sí, en cambio, contener fuerte carga parenética. Hallamos unidos el tema de la guerra y el vino (2), el vino (11) «saca vino rojo hasta la hez, porque no podremos abstenernos de beber en esta guardia», el abandono del escudo (12) "salvé mi vida, ¿qué me importa aquel escudo? ¿Váyase a paseo! Ya me procuraré otro que no sea peor», el 
epigrama funerario, consolatorio, al que se da ahora carácter literario $(20,21)$. Otras veces parece dirigirse a los soldados (9).

Así, pues, son continuas las referencias a la ciudad, a la guerra impulsada por su ciudad, a las consecuencias de la guerra, a la injusticia, etc. Tan estrecha en la relación de este poeta lírico con su ciudad que él, no sólo luchó en defensa de los intereses de la misma $(1,2,107,161)$, aunque, llegado el caso ridiculizara las hazañas poco heroicas del ejército (167), sino que, al parecer, por ella murió en acción bélica a manos de un naxio llamado Calondas ${ }^{3}$.

\section{b) Calino de Efeso}

Contemporáneo de Arquíloco. En sus poemas vemos el uso de la flauta en campañas militares, algo bien conocido desde Homero (Il. X 13; XVIII 495). Con tal objetivo será empleado dichó instrumento musical, también en el siglo vil, por Tirteo y Mimnermo.

Calino (y luego Tirteo en Esparta; Solón en Atenas) ocuparon cargos públicos y utilizaron la poesía como medio de acción política. El Fr. 1 es la exhortación directa a sus conciudadanos, no a buscar la gloria, como sucedía en Homero, sino a salvar la ciudad frente a los ataques de sus enemigos, los cimerios. La influencia de Homero es palpable en lengua, imágenes y tono, pero el objetivo ha cambiado: se trata ahora de la defensa de una ciudad concreta.

Aparece un tema importante: el pueblo no quiere al que vuelve indemne de la batalla, mientras que añora a un héroe que muere en combate.

La lírica, a la sazón, ocupa un lugar semejante al que luego tendrá la oratoria en el siglo Iv. Los poetas están convencidos de que el destino de sus pueblos dependen de ellos, $y$, por consiguiente, se dedican con intensidad y resolución a la vida política: profeta, predicador, político, sabio son funciones desempeñadas normalmente por los poetas.

\section{c) Tirteo}

Corresponde a la segunda mitad del siglo vir a. C. Esparta vive en pie de guerra contra los mesenios: es la segunda guerra mesénica. Realmente

${ }^{3}$ Cf. The Cambridge History of Classical Literature. Greek Literature, Ed. P.E. EasterlingB.M.W. Knox, Cambridge 1985. p. 117; F. R. ADRADOS, «Arquiloco» en Historia de la Literatura griega, ed. J. A. López Férez, Madrid 1988, p. 123. 
los espàrtanos los tenían esclavizados: «abrumados por grandes cargas, igual que asnos, llevando la mitad del fruto que la tierra produce» (5). Tirteo, sin lugar a dudas, es el abanderado de la represión. Prácticamente todos los fragmentos son una parénesis, o exhortación, dirigida a los jóvenes espartanos para atacar al enemigo. No están seguros los estudiosos de si sus elegías eran cantadas en algún banquete o fiesta comunal antes de las batallas, o bien se entonaban durante la marcha del ejército 4.

Parenéticos son los fragmentos 1, ataque a una fortaleza mesenia; 6 , deshonor del cobarde y gloria de los jóvenes héroes, tanto durante su vida como tras la muerte; 7 , los que permanecen firmes en la formación son los que se salvan. También lo son 2 y 3: la llamada Eunomía, pero tienen un propósito diferente. A saber, pretenden confirmar la influencia de Zeus y Apolo en el régimem espartano, como si éste dios hubiera profetizado la retra o constitución de Licurgo.

Altamente interesante es 8: cuál es la verdadera areté. Es de tema simposiaco, con un final parenético: «que todos intenten llegar al más alto grado de esa suprema excelencia, al no huir de la guerra» (vv. 41-44). Nos encontramos con una exposición lingüística relevante, pues tras cinco dís-

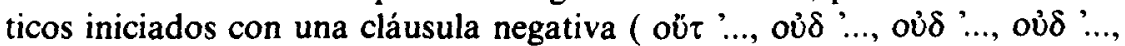
oủ $\delta$...), seguidos de uno intermedio, viene en posición relevante, enfática,

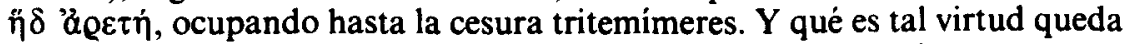
expuesto con su toda crudeza: contemplar la matanza sangrienta y atacar al enemigo acercándosele.

Tirteo viste de lenguaje épico un asunto contemporáneo, pero realmente el contenido era propicio para ello: la lucha sangrienta y el heroismo guerrero. Estamos en el mismo plano que en la Iliada, pero lo nuevo ahora es la idea de una comunidad ciudadana para la que todos viven y mueren por encima del individuo. La areté homérica, el heroísmo individual, son transformados ahora en amor a la patria hasta dar la vida por ella.

Ya Demóstenes (XVIII 170) advirtió que cuando Tirteo dice "yo" habla por su boca la voz pública de su patria. El poeta, en este caso, se manifiesta como educador. No sólo insufla coraje y valor en los batallones, sino que trata de convencer a los jóvenes que luchan en el frente acerca del origen divino del estado espartano. Los versos heroicos de Tirteo resonarán ya siempre por Grecia en epitafios y simposios.

Algún rasgo más podemos aportar respecto a la sociedad a la que se dirigían estos versos. Tirteo (6.23-24) nos habla de cómo están en primera linea de batalla «hombres de cabeza ya blanca y barba cana», y se refiere a "viejos» (6.20) que están en el frente. Todo el pueblo, quizás, oiría estos versos, y, en todo caso, el mensaje está claro: son los jóvenes los que, llenos

${ }^{4}$ Cf. Cambridge... (CHGL), p. 131. 
de coraje, han de combatir en defensa de la ciudad. De otra parte, el joven valeroso, si queda vivo, produce al ser visto «admiración en los hombres y amor en las mujeres» (6.27-29). Al viejo que ha sido valiente le ceden el asiento jóvenes y ancianos (8.41-42).

\section{d) Semónides de Amorgos}

Noble, como Arquíloco, es algo más joven que éste. Nacido en Samos, dirigió una colonia que se estableció en Amorgos.

Elegía pronunciada en el banquete seria la famosa que habla de que "cual la generación de las hojas, tal la de los hombres» (1. Cf. Il. VI 146).

De entre sus yambos debemos fijarnos en 8, que tiene 118 versos. El yambo de las mujeres, en que aparecen nueve tipos desfavorables y uno bueno. Tenemos una gnome inicial: «la divinidad hizo diferente el modo de ser de las mujeres».

El antifeminismo en la literatura griega comienza pronto. Un rasgo evidente cabe verlo en la Pandora de Hesíodo ( $O p .80$ ss.), que tiene ciertos precedentes orientales. Pero en Semónides hemos de ver más bien la influencia de las fiestas demetriacas en que había pullas y escarnios entre hombres y mujeres, formando parte del ritual. Los enfrentamientos entre los dos sexos son un tema literario de elevado rendimiento en la literatura griega. Pero, además, hemos de ver en 8 un fin didáctico: dar consejos para elegir mujer. Para ello nada mejor que el uso de la fábula, bien representada en el texto que nos ocupa. Los estudiosos no se deciden a la hora de pronunciarse acerca de si tal yambo fue cantado en una fiesta o en un banquete, pero de lo que no cabe duda es de que en poemas como éste queda manifiesta la intima relación entre lírica y sociedad a la que se dirige.

\section{e) Hiponacte de Éfeso}

Aristócrata desterrado en Clazómenas, tiene su momento de auge hacia la mitad del siglo vi a. C. Ni siquiera la crítica más feroz ha podido decir que Búpalo, Atenis y el padre de ambos, Arquermo, son motivos literarios, pues contamos con dos inscripciones de la época que contienen sus nombres. En cambio no sabemos lo que hay de realidad y de ficción literaria en lo referente a Arete, novia de Búpalo $(12,15)$, con la que el poeta bebe (13, 14) y se acuesta, siendo sorprendido en el acto amoroso (84). 
Hay mucho de ficción literaria en la obra hiponactea: su pobreza (3339), por ejemplo. No aparece en él por parte alguna el motivo del patriotismo. Sirvió, en cambio, como modelo a los cómicos. Pero, no obstante, muchos de los fragmentos que nos han sido transmitidos muestran una relación del poeta con su ciudad. Así, 1, pronunciado ante todos los ciudadanos: «Oíd a Hiponacte, pues acabo de llegar, joh clazomenios!, Búpalo y Atenis...». Es algo que nos anticipa lo que leeremos en Solón.

También sus yambos de banquete ofrecen motivos que serán imitados luego por los cínicos. Así, el ritual del fármaco, sin duda usădo para hacer reír a los comensales a fuerza de befa sobre personajes afines al poeta (56, $57,60,69)$. El mismo fin perseguiría el tema de la restauración de la virilidad $(78,92)$, en que los escarabajos adelantan ciertos juegos verbales de Aristófanes.

Hiponacte se dirige a una sociedad muy lejana del mundo heroico. Encontramos una vida sórdida, y un vocabulario lleno de regionalismos: pálmys «señor», bêkos "pan», como en Heródoto (II 2); una mujer aparece hablando lidio (92); tenemos palabras exageradamente largas y muy expresivas, que sirven como, una primicia de las piruetas léxicas aristofánicas. No obstante, por muy popular que esta lengua parezca ser, muestra gran influencia de Homero y pone de relieve la cultura literaria del autor y del auditorio. Por ejemplo, 135 nos habla del «Eurimedontiada, el estómago de cuchillon: fórmula y construcción a lo homérico, pero intención totalmente distinta.

\section{f) Solón}

Sabemos que fue arconte de Atenas en 594/593 a. C. con poderes especiales. No podemos extendernos en la situación social y económica que hizo necesaria la presencia de nuestro autor como árbitro entre los aristócratas enriquecidos y llenos de soberbia y un gran número de atenienses que vivían en condiciones miserables, esclavizados por deudas contraidas con los terratenientes, y forzados, incluso, a vivir en el exilio.

En Solón tenemos por primera vez a un político que agita al pueblo, defiende públicamente su política y anuncia ante todos su programa ${ }^{5}$. Durante unos 50 años nuestro poeta exhortó a sus conciudadanos; denota clara conciencia de la responsabilidad que tiene ante la comunidad en que vive. El ideal de justicia, presente ya en Hesíodo, cobra ahora especial resonancia.

${ }^{5}$ Cf. $C H G L$, p. 146. 
Ahora bien, la injusticia no engendra, como en Hesiodo, malas cosechas, hambre, abortos, guerra y muerte ( $O p$. 243-248), sino desorden social: unos pocos se enriquecen, mientras que muchos viven en el exilio o como esclavos (24). Hay una perfecta sintonía entre el poeta y su pueblo. A grandes rasgos, su producción puede dividirse en elegías (parenéticas), y yambos y tetrámetros trocaicos (de crítica y ataque, aunque contienen asimismo otros motivos).

De las elegías (1-23) conservamos 219 versos, de los, al menos, 5.000 que compuso. Destaca 2, llamada Salamina. Es una parénesis ante todo el pueblo ateniense. Pronunciada en el ágora, o quizás en alguna fiesta de la ciudad. El poeta se finge loco, a causa del decreto dado por los atenienses con el que se castigaba a muerte a quien hablara de reconquistar tal isla, entonces en manos de los megarenses. En el poema cabe ver, no sólo una subversión ideológica, sino también una verdadera representación dramática.

En otros fragmentos (8-10) Solón da advertencias contra la tiranía. En 3 (Eunomía), con lenguaje directo, claro, próximo a la lengua transparente de los oradores áticos, echa sobre sus conciudadanos la culpa de los fracasos que están sufriendo: «los mismos ciudadanos, con sus locuras, quieren destruir nuestra ciudad, cediendo a la persuasión de las riquezas» (3. 5-6). Solón afirma sin ambages: «enseñar eso a los atenienses me lo ordena mi ánimo» (3. 29). Tanto 3 como 4 (Disnomia), donde se recogen las repercusiones políticas de la injusticia, parecen haber sido pronunciados ante una fiesta comunal. Por otra parte se confirma una idea presente ya en Homero (Od. I 32 ss.): la responsabilidad humana queda claramente establecida (11.1-2): «si por vuestra maldad os han ocurrido cosas penosas, no echéis a los dioses la culpa de ellas".

Profundo sentimiento religioso encierra 1: es la plegaria a las Musas. El poeta sólo acepta la riqueza que viene sin engaño, la que se adquiere de modo justo, pues, de lo contrario, recae el castigo sobre los autores de injusticia o sobre sus descendientes. En tal poema es clara la influencia del pensamiento hesiódico.

Solón ofrece también temas de banquete. Se habla del amor homosexual (12), o de disfrutar de amor masculino o femenino cuando llegue la edad apropiada para ello (14). Se elogia la vida aristocrática (13); se alude, asimismo, al progreso y trascurso de la vida, en sus facetas física e intelectual, distribuida en períodos de siete años (19), donde se aconseja casarse en el quinto periodo, es decir, entre 35 y 41 años. Se fija el sexto período como culminación en todos los aspectos, aunque la inteligencia y la lengua sobresalen en el séptimo y octavo: no es a destiempo que la muerte llegue al final del décimo, es decir, a los 77 años. En otro fragmento, el poeta se manifiesta contra Mimnermo, que habla de morir a los 60 años; para el sabio ateniense los 80 años (22) son la edad adecuada para el último trance. 
En los yambos (23-27) se habla, por ejemplo, de los placeres del banquete (26). Solón afirma que ningún otro, excepto él, habría contenido al pueblo, ni tampoco habria cesado en su cargo hasta batir la leche y sacar la manteca (25). Menciona que ha devuelto al Ática a los que habían sido vendidos como esclavos o se habían exiliado por causa de su apremiante pobreza; tantos años estuvieron fuera que ya no hablaban el dialecto ático. Afirma que escribió leyes para el hombre del pueblo y para el rico, estableciendo para ambos una justicia recta. Pero para ello hubo de revolverse como lobo entre muchas perras (24).

Veíamos que en Arquíloco e Hiponacte los trímetros yámbicos servían, entre otros fines, para el ataque personal, y que en Semónides se utilizan para denostar a las mujeres. Pero en Solón el yambo se carga de seriedad y dignidad. Se ha dicho que los yambos solónicos parecen un discurso de tragedia clásica, pues incluso su estructura es diferente de la que tenían hasta entonces, ya que ahora las sentencias son largas y van abarcando un tema tras otro hasta completar el sentido ${ }^{6}$.

\section{g) Mimnermo de Colofón}

Contemporáneo de Solón, fue natural de Esmirna, pero fundador de Colofón. He aquí otro caso de la estrecha relación entre lírica y sociedad para la que se escribe. Muestra los avatares de la colonización de las costas de Jonia a comienzos del siglo vi a. C. Su nombre y el de su padre son asiáticos. Probablemente fue poeta ambulante; él mismo nos habla de Nano, su flautista y amante. Estamos ante un mundo distinto del que hasta ahora hemos visto, con ciertos paralelos, desde luego, en Hiponante: es una sociedad llena de mezclas y altibajos sociales y económicos.

Su obra está compuesta casi exclusivamente de elegías, pues sólo nos ha llegado un fragmento yámbico (15). De las elegías, los fragmentos 1-11 proceden de Nano, posible colección de pequeñas elegías de argumento erótico. Se abordan allí los temas de la vejez y la muerte; la vida sin Afrodita no es deseable (1); la brevedad de la juventud (2); la muerte debe llegar a los 60 años, sin enfermedades ni crueles preocupaciones (6). Aparte de eso, los fragmentos 12,12 A y 13 corresponden a una Esmirneida, poema en que se aborda la fundación de Esmirna: procedentes de Pilo, y partiendo de Colofón, en la «bella Asia», los fundadores llegaron a Esmirna por designio de los dioses (12).

Mimnermo nos presenta una sociedad decadente, la de una Jonia sensual

- H. FränKEL, Early Greek poetry and philosophy, trad. ing., Nueva York-Londres 1975, pp. 226 ss. (El original alemán es de 1951) (1962²). 
e insegura. La vejez es considerada como el supremo mal: «es motivo de odio para los jóvenes y de desprecio para las mujeres» (1. 9-10); «Cuando pasa la juventud, ni siquiera el padre, antes tan hermoso, es honrado y querido por sus hijos» (3); "Zeus concedió a Titono un infortunio eterno, la vejez, que es peor que la muerte funesta» (4).

\section{h) Teognis de Mégara}

Nacido hacia el 544 a. C., el último suceso histórico mencionado es la invasión persa (480 a. C.). La democracia, instaurada en Mégara hacia 570 a. C., fue derrocada a causa del desorden y anarquía en que degeneró (Aristóteles, Pol. 1304 b 34). Pero hubo, después, luchas entre oligarcas y demócratas. En algunas de esas revueltas, dificiles de precisar cronológicamente, los demócratas echaron al exilio a muchos aristócratas, entre los cuales quizás estaría Teognis. En todo caso sabemos, por sus palabras, que le confiscaron las tierras (364 ss., 1197 ss.).

No podemos abordar el arduo problema de qué es de Teognis dentro de la llamada Colección teognidea, pero sí debemos decir que no más de 250 versos de los 1.389 que comprende la misma. Un punto importante respecto a la relación de Teognis con su público es el sello de su obra. Normalmente se afirma que "OO Cirno!», repetido aquí y allá, es la marca o sello con que el poeta quiere delimitar lo que ha escrito para que sus versos jamás sean robados (20). Pero, por comparación con casos semejantes, el sello es más bien el nombre del poeta que aparece en la secuencia "son versos de Teognis de Mégara; es famoso en todas las naciones» (22-23). Se piensa hoy que con "sello («tenga yo que los compongo un sello de estos versos») (19) puede aludirse al hecho de que el poeta hubiera depositado su obra en un templo o lugar sagrado, bajo sello, como leemos que hiciera también Heráclito ${ }^{7}$. Todo esto sirvió de muy poco, pues sabemos que fue pronto imitado, y durante el siglo $\mathrm{v}$ a. $\mathrm{C}$. muchas otras elegías de diversas procedencias se entremezclaron con las auténticas.

Teognis nos presenta una sociedad dividida en malos y buenos (183192). Los primeros son los aristócratas de siempre, a los que sin duda pertenece el poeta; los segundos, son las nuevas clases enriquecidas. Nuestro autor aconseja no casarse con hijas de nuevos ricos, y afirma que pocos de entre éstos son de fiar (73 ss.); no conviene hacerse amigo de ellos (53 ss.); personalmente siente temor ante la pobreza (173 ss.; 179 ss.).

' Se dice que Heráclito de Éfeso depositó su Sobre la naturaleza en el santuario de Ártemis. Cf. 22 A 1, 6 D.-K. (Diógenes Laercio IX 6). 
De otra parte, el escritor manifiesta sus dudas respecto a la educación (429-433, 435-438), habla de la ingratitud de Cirno (237-247, 251-254). Prueba del cambio impuesto por los nuevos tiempos es el consejo de acomodarse al lugar y circunstancias en que cada uno se encuentra: «aprópiate la manera de ser del pulpo retorcido, que se muestra semejante a la roca a que está adherido; acomódate ahora a una y muda luego el color. La habilidad es preferible a la intransigencia» (215-218).

Encontramos vocabulario homérico y fórmulas homéricas también, pero todo se ajusta ahora a la nueva situación. Tenemos temas tradicionales como el vino, el banquete, la homosexualidad (983-988). Pero hay otras indicaciones en consonancia con las convulsiones sociales de la época: el tema de la traición del amigo (87-92); la terrible crítica de la moneda, pues las nuevas clases enriquecidas suponian un revés definitivo para la aristocracia terrateniente. La moneda, se nos dice, «tiene el mayor poderío de todas las cosas» (718. Cf. 699-704, 713-718).

En suma, Teognis se dirige a una clase aristocrática empobrecida, que necesita pactar con las nuevas clases enriquecidas. No obstante, los aristócratas venidos a menos, no han perdido sus antiguos ideales: la medida (335-336, 615-616), la oportunidad (401), el buen juicio (635-636; 895-896), etcétera.

Para quiénes se han escrito las elegías de Teognis es otro problema no bien resuelto. Buena parte de los poemas están destinados a ser leídos en el banquete: el vino y sus consecuencias, los modales durante el festín, temas como los de la medida, la oportunidad, referencias a la política y la vida humana, en general. Pero también hay himnos a los dioses (1087-1090), epitafios (1209-1216), acertijos (257-260, 861-864, 1229-1230), etc. Dónde serían entonadas estas elegías, muchas de ellas incorporadas a la llamada Colección a lo largo del siglo $\mathrm{v}$, no es dado contestarlo con seguridad.

\section{LÍrICA CORAL ARCAICA}

\section{Alcmán $^{8}$}

Constituye nuestro testimonio más antiguo de lírica coral. Aunque se ha hablado de lírica mixta, en el sentido de que los proemios serían monódicos, e irían seguidos del coro propiamente dicho, hoy, casi todos los estudiosos se inclinan por ver los poemas de Alcmán como interpretados por un coro, sin partes monódicas. Estamos mal informados acerca de la cronología, pero todos los indicios apuntan hacia el 612-609 como el mo-

\footnotetext{
${ }^{8}$ Debemos mucho al capítulo correspondiente de $C H G L$, pp. 168-185, obra de Ch. SEGAL.
} 
mento de esplendor de Alcmán. Varios testimonios indican que nació en Sardes (Lidia), y desde alli habría sido llamado a Esparta. No obstante, el dominio del dialecto local, la familiaridad con las costumbres espartanas y su enterramiento junto al santuario de Helena, en Esparta también (Pausanias III 15, 3), hablan en favor de un origen espartano o, al menos laconio, de nuestro autor?.

Todo lo dicho tiene gran importancia para el tema central de nuestro estudio: la sociedad para la que escribía la lírica en sus distintas manifestaciones. La Esparta de Alcmán (siglo vII a. C.) es muy distinta de la que nos presentan los escritores áticos a partir del siglo IV a. C. encerrada en sí misma y sin contactos con el resto de Grecia. En el siglo vil a. C. son precisamente Esparta y Corinto (y no Atenas) los centros culturales y económicos más florecientes en la Grecia peninsular. Estamos relativamente bien informados por los resultados arqueológicos del esplendoroso auge de las artes en Esparta entre 650 y 550 a.C., es decir, tras la segunda guerra mesénica, la cantada por Tirteo. En el siglo VII Esparta tenía magníficos templos, ricos en mármoles, marfil, bronce y terracota. Por otra parte, se ha podido decir que la riqueza y colorido de la cerámica de tal período está en estrecha relación con el arte poética de Alcmán.

Desde fines del VII hasta las primeras décadas del vi a. C. Esparta logró reunir a excelentes representantes de las artes y las letras. Allí vivieron y trabajaron Alcmán, quizás de Sardes, Terpandro de Lesbos, Taletas de Gortina, Jenócrito de Locros, Sácadas de Argos, y tantos otros. Había fiestas famosas: Jacintas, Carneas, Gimnopedias eran celebradas con esplendor, y los coros presentados en ocasiones solemnes eran bien conocidos en toda Grecia (Asi dice Píndaro refiriéndose a Esparta: «donde son preeminentes los consejos de los ancianos, las lanzas de los jóvenes, los coros, la Musa y Aglaya" (Fr. 199 S.-M.).

Entrando en la obra de Alcmán no podemos detenernos en toda ella, ni siquiera en el significado del término partenio con que se titula a sus composiciones poéticas. Sí podemos precisar que se trata de una clasificación alejandrina, pues ni en época arcaica ni clásica existía tal vocablo como género poético constituido. Nos ceñiremos al fragmento 1 , conocido desde hace más de 100 años, gracias al papiro del Louvre, y que ha sido objeto de numerosas investigaciones. Nos limitaremos a los puntos más relevantes que hacen ver la interconexión entre lírica y sociedad a la que va dirigida. El poema fue compuesto para ser cantado por un coro de muchachas en ocasión de un festival religioso no bien conocido.

Asimismo somos deudores de C. CALAME. Les choeurs de jeunes filles en Grèce archaïque. I. Morphologie, function religieuse et sociale; II. Alcman, Roma 1977. Tiene abundante y muy buena bibliografia.

${ }^{9}$ CHGL, pp. 168-169. 
Se abre el fragmento con un largo contenido mítico mal conservado. La derrota de los hijos de Hipocoonte. El mito en este texto tiene indudable función política: legitimar el orden cívico lacedemonio, mediante el destronamiento de Hipocoonte, hermanastro de Tindáreo, y el restablecimiento de este último en el poder real espartano. Sabemos por otras fuentes que un hijo de Hipocoonte habia intentado violar a Helena. Así, pues, aparte de la reinstauración de Tindáreo, en la que Heracles tuvo papel decisivo, el mito apuntaba a las rivalidades amorosas entre jóvenes, siendo por tanto apropiado para ser expuesto ante jóvenes cuya iniciación significa el paso al mundo de los adultos. De otra parte, los hijos de los espartanos, descendientes de Tindáreo y de Hipocoonte, se disputan en cierto sentido a las jóvenes que están siendo iniciadas: con ello el ritual sagrado es completo y fácil de comprender por todos los asistentes a la fiesta comunal.

Un segundo mito (vv. 22-35) muy fragmentario, parece referirse al castigo de un crimen cometido contra los dioses. Ello entroncaría bien con la parte que no nos ha llegado, donde se atenta contra el honor de Helena, una divinidad en Esparta. Posiblemente lo de «que ningún hombre vuele hasta el cielo ni intente casarse con Afrodita" (vv.16-17) hace ver que el mito está en relación con el matrimonio, y, a la vez, es una llamada a la moderación y a saber elegir esposa. La mención de los Hipocoóntidas tiene indudable sabor local: esto va a ser una característica de la lírica coral. Estesícoro, Píndaro, etc., sacarán a la luz mitos locales de escasa difusión en el resto de Grecia, referentes a un héroe epónimo o a una familia residente en una ciudad concreta. A su vez, nombrar a «Poros y Esa de todos... los más antiguos» (v.13) indica el triunfo del orden moral, una función del mito que será normal desde ahora, llegando a su apogeo en los poemas pindáricos.

El Coro habla luego de Ágido, que va a ser iniciada, y a quien se compara con el Sol. Este detalle (v.41) tiene que ver con el culto religioso de iniciación. El rito de paso se celebra al salir el sol, momento en que se evoluciona paulatinamente desde la oscuridad a la luz, desde el estado de no iniciado, al de iniciado.

Ágido, guiada por Hagesícora, va a pasar al mundo de los iniciados, sirviendo de modelo a las otras ocho muchachas, coreutas también. Hagesícora, por su parte, desempeña una función múltiple: pedagógica, amorosa, religiosa. En Esparta sólo las jóvenes de las mejores familias eran iniciadas, y, tras ello, llegado el momento, servian de coregos. Las otras muchachas, integrantes del Coro, pertenecen al pueblo espartano, no a la familia real, y se benefician y participan de los efectos de la iniciación. Ágido está en relación etimológicamente con los Agiadas, una de las familias reales de Esparta.

Toda la comunidad asiste a los festivales que celebran el momento culminante del ritual, el paso de la adolescencia a la edad adulta. Iniciaciones 
semejantes tenian lugar en Creta, por lo que a muchachos se refiere. En las poesías de Safo el léxico deja traslucirse la alusión a ritos similares.

Hagesícora, «la que conduce el coro», sobresale en belleza sobre las demás integrantes del Coro. La comparación de Hagesicora y de Ágido con caballos selectos, la mención del oro, púrpura y otros ornatos de gran valor (vv.50 ss.) van a ser motivos literarios de elevado rendimiento en lo sucesivo. Píndaro acudirá a ellos con frecuencia. Pero, de otro lado, indican la prosperidad económica de la Esparta de la época. Punto oscuro es el pháros (v.61), traducido por "peplo", "velo sagrado", pero glosado en los escolios como "arado". La diosa a quien tratan de agradar y complacer es llamada Aotis (v.87), está en relación con el alba, y, quizás, con el matrimonio y la fertilidad. En cambio, no es segura la referencia a Ártemis Ortia. En realidad no sabemos bien si el poema que estudiamos está en conexión con el culto a Ártemis, o con el de Helena. Estudios recientes parecen apuntar a la segunda posibilidad. En todo caso por diversas fuentes sabemos que las jóvenes eran iniciadas en Esparta en varios ritos ancestrales: en las Jacintas, en las fiestas de Afrodita-Hera, en los festivales en honor de las Leucípides, y en los celebrados para honrar a Helena.

La parte erótica viene después: «ni puedes ir donde Enesímbrota y decir: "Tenga yo a Astáfide y que me mire Filila y Demareta y Viantemis, digna de amor". Pero Hagesícora me consume». Hay elementos que apuntan sin duda a una situación erótica. Se ha visto que Enesímbrota sería una especie de hechicera experta en filtros amorosos; de otro lado, eratá (v.76), y teirei (v.77) muestran que nos hallamos ante una escena de amor homosexual. El homoerotismo, por lo demás, cumplia un papel institucional en la Esparta del momento, y no sólo allí. Ya H. Diels ${ }^{10}$ precisó en 1896 que en el fragmento estudiado hay expresiones reveladoras de una relación homosexual, y pensó que klenná (v.44) era similar al mismo adjetivo, en género masculino, usado en Creta para designar al joven elegido por el amante para el proceso de iniciación. Pensó Diels que Hagesicora sería la «amada» y Ágido la «amante». Hoy se está de acuerdo en que ocurre lo contrario.

Siguiendo con el texto, y limitándonos al objetivo que nos hemos marcado, el Coro llama a Hagesícora "caballo bridón» (v.92), lo que viene a significar que es el encargado de conducir y educar a las demás muchachas integrantes del Coro: equivale a "caballo conductor» (Cf. Sófocles, El. 721 ss. Eurípides, IA $218 \mathrm{ss}$.). El papel pedagógico de la corego queda demostrado cuando se la compara abiertamente con el piloto de una nave, al que hay que obedecer (akoúen) (v.95).

Si en versos anteriores aparece la mención de Hagesícora y Ágido, ¿comparadas? ¿enfrentadas? con palomas ( $v .60)$, aunque se discute el sentido y

to «Alkmans Partheneion», Hermes 31, 1896, pp. 339-374. 
a quiénes se refiere tal adjetivo, más adelante, el Coro se llama a sí mismo «lechuza» (v.77). Una vez más, creemos encontrar la oposición entre el día y la noche, entre un ave diurna, y por lo demás blanca, inmaculada, y un ave nocturna, caracterizada además por un color oscuro. La oposición entre iniciados/no iniciados sería subrayada de nuevo.

No nos es dado abordar el examen lingüístico del texto para hacer ver que esta lírica coral está lejos de ser primitiva en su expresión formal, pues los ecos verbales, paralelismos, figuras retóricas (símil, priamel), dicción rica en adjetivos compuestos, resonancias homéricas (caballos, noche eterna) al servicio de nuevas intenciones poéticas, todo ello muestra que Alcmán es un consumado poeta conocedor de los recursos del arte poética y de la tradición literaria. Pero, al mismo tiempo, el lugar, componentes, ocasión, referencias del partenio que hemos visto, son indicadores visibles de la unión del poeta lírico con la vida social y política, algo normal en la Esparta de fines del siglo vil a. C. y de los primeros decenios del vl.

El poeta y la sociedad para la que escribe sus poemas forman un todo armónico; la poesía está al servicio de los intereses de la comunidad. Puede decirse que, si en otros rituales los jóvenes espartanos eran preparados para el combate y para resistir las pruebas físicas más duras, las jóvenes espartanas mediante rituales como el visto, son iniciadas para pertenecer al mundo adulto, en definitiva, para ser madres de excelentes guerreros, y, al tiempo, valientes esposas. El Coro, así, tiene evidente función institucional. 


\section{BIBLIOGRAFÍA}

(Muy breve y selecta)

(Consúltense ante todo las obras de conjunto citadas en notas 1, 2, 3, 6 y 8 . Destacan también por su rica bibliografia).

Además, pueden ser de interés:

F. R. Adrados, Orígenes de la lírica griega, Madrid 1976.

— : El mundo de la lírica griega arcaica, Madrid 1981.

D. ARnould, Guerre et paix dans la poésie grecque. De Callinos à Pindare, Nueva York 1981.

C. M. Bowra, Greek Lyric Poetry. From Alcman to Simonides, Oxford 19612.

— : Introducción a la Literatura griega, trad. esp. Madrid 1968, pp. 87-170.

D. A. CAMPBell, The golden Lyre: the themes of the Greek Lyric poets, Londres 1983.

J. A. Davison, From Archilochos to Pindar, Londres 1968.

B. Gentili, "Aspetti del rapporto poeta-commitente-auditorio nella lirica corale greca», StudUrb 39, 1965, pp. 70-78.

- : «Poeta-comitente-público», en Historia y civilización de los griegos, trad. esp., III, Barcelona 1981, pp. 213-261.

— : «Lirica greca arcaica e tardo-arcaica», en Introduzione allo studio della cultura classica, Milán, s.a., pp. 57-105. 
W. JAEger; Paideia. Ideales de la cultura griega, trad. esp., México $1968^{2}$, pp. 84149; 181-211.

A. M. Komornicka, «Poésie et poète. Termes et notions dans la littérature grecque», $G F F$ 7, 1984, pp. 3-17.

C. O. PAVese, La lirica corale greca. Alcmane, Simonide, Pindaro, Bacchilide. Introduzione, indice dei temi e dei motivi, Roma 1979. 